\title{
Vendor Industry: Revolution in Economic Growth
}

\author{
Nisar Ahmad \\ Imperial College of Business Studies Lahore, Pakistan \\ dean@imperial.edu.pk
}

\begin{abstract}
The developing countries with ample human resources can be the major benefactors of vendor industry. Such countries have high potential of using people, who otherwise may be fully or partially unemployed most of the time. Poor countries are not benefiting because of financial/material foreign assistance from rich countries. In fact, many of these countries are accumulating huge foreign debts without any trickledown effect to improve the economic welfare of the common person. Poor people because of lack of education and opportunities to earn income are forced to live with minimum of food intake and poor health facilities. Empowering the common person should be the ultimate aim where national resources are to be employed. This will necessarily mean reversing national priorities, which presently seem to have painfully neglected the welfare of the majority of people living in the poor countries. The suggested model in this Paper presents an approach similar to the one adopted by the Grameen Bank. The idea was to extend interest free small loans to the eligible families (having required skill and basic education) to do business on their own. However, all this is to be handled through the private sector, and monitored by the banking authorities for repayment of all those loans within a feasible period. This Paper provides strong justification for expanding vendor industry in developing countries on terms and conditions, which can motivate and provide incentives for the poor families to earn and live an honorable life of comfort and respect in the society. The Paper analysis the effectiveness of the western advocated theories of economic growth and suggests a complete turnaround in the philosophy of national resource use. The economic growth concept advocated in this Paper is built on the ground that the developing countries cannot benefit from the foreign assistance, rather the people (a valuable resource for the poor countries) in these countries need to be focused, educated, trained and provided with the opportunities to work and to do business in their specialized domain so that they can add value to the national product (GDP).
\end{abstract}

Keywords: Valuable Resource, Empowering, Revolution, Growth Theories, Interest Free, incentives, specialized domain.

\section{Introduction}

Vendor industry is to stand as the most powerful competitive strength to fight out global competition for labor surplus countries. On the lines of Adam Smith's philosophy of Division of Labor, poor countries with high unemployment rates can use their idle sitting human power to do some thing small but marketable. Human beings have capability and adaptability to perform many functions, a unique quality which no other resource can claim. In the case of Japan, after World War II, large-scale destruction of physical capital left only option for Japan to make best use of the human power. Singapore is another example, where in the absence of mineral and material resources, human power has done wonders and placed the country among the most prosperous countries of the world. Business organizations all over the world are in search of low cost inputs to keep the prices of their products/services low enough to gain competitive edge among its competitors. Dowling et al (2004) presented sufficient evidence to suggest that the comparative advantage of many of the less developed countries in the supply of labor, skilled and semiskilled professionals, and raw materials, along with many of the concessions allowed to the foreign investors, becoming increasingly attractive business centers for well-established business firms. The Japanese auto manufacturers, Toyota, Honda and the like have made their presence all over the world, including Less Developed Countries to take the advantage of many of the inputs and concessions given to the foreign investors. Pilkington (1998) while comparing auto manufacturing with many other fast growing consumer products, such as PCs, revealed that the components needed to make an auto is far greater and therefore, the outsourcing of the auto components can provide ample job opportunities to the labor surplus countries.

Majority of people living in poor countries are considered surplus and are their economic welfare is never in view when national priority programs are executed. Given the availability of surplus human power in 
developing countries, a major turnaround can be organized by introducing universal education, skilllearning programs for the qualified, and providing universal facility of small loans on the lines of GrameenBank. This will provide opportunities and options for the educated and skilled labor to do some thing on their own to earn a respectable living. China, South Korea and India seem to have gainfully employed their people in vendor industry. Knowing the demand for small cars is likely to increase exponentially in the coming years, these countries have supported the indigenous production of auto parts, and every one of them is in the race of developing small car hub of the world. By extending loaning facility to the qualified and skilled can bring output revolution in auto industry just as Nobel Laureate Prof. Muhammad Yunus of Bangladesh did by establishing Grameen Bank. A revolution, which captured the entire world. On the same lines each family can be activated and can be made to enter a work program, which they can do, on their own by selling their idle time. In such programs low-income families can make excellent contribution to the growth of national GDP. )

\section{Growth Potential}

Countries whether rich or poor, have ample material and human resources to run their economies for ensuring comfortable life for all its nationals. Pakistan has excellent agriculture potential in addition to several material and mineral resources, Nigeria has plenty of oil, Malawi has tobacco, and Sudan has Cotton and so on but still they are poor, rather poorest among poor nations of the world. In fact, the most powerful resource in any country is its people. If they are educated, trained, and made to earn their own living, they can watch their interest and elect or select a competent ruler to run their economies. We have several role models suggesting that you need to have Will to do good to your people. Singapore, South Korea. Japan and Malaysia are the excellent examples where will and drive played an active role in turning around the economic welfare of the common person. Singapore a small country of some 5 million people, without much material resources of their own was among the developing countries, before Lee Kuan Yew took over as a Prime Minister of Singapore. A quality of leadership provided by Lee Kuan Yew placed Singapore among the highest per capita income earning countries of the World ( among the top ten- Year 2011). Similarly, because of Mohatir Mohammad of Malaysia, the country is fast moving on the path of prosperity. Leadership with a strong Will is the primary pre-requisite for economic growth of the common person in developing countries. Generally living on other people's income (borrowing) is not recognized as a dignified way of living in a social society.

Table 1:Poverty Levels - Year 2011

\begin{tabular}{|c|c|c|}
\hline Country & $\begin{array}{l}\text { Total Population } \\
\text { (Figures in million) }\end{array}$ & $\begin{array}{c}\text { Income Poor People- } \$ 1.25 \text { per day } \\
\text { (As a \% of Total Population) }\end{array}$ \\
\hline Tanzania & 42.747 & 88.5 \\
\hline Liberia & 3.787 & 83.7 \\
\hline Burundi & 10.216 & 81.3 \\
\hline Rwanda & 11.370 & 76.6 \\
\hline Mozambique & 22.949 & 74.7 \\
\hline Malawi & 15.879 & 73.9 \\
\hline Guinea & 10.601 & 70.1 \\
\hline Madagascar & 21.926 & 67.8 \\
\hline Niger & 15.731 & 65.9 \\
\hline Nigeria & 155.214 & 64.4 \\
\hline Zambia & 13.881 & 64.3 \\
\hline Swaziland & 1.370 & 62.9 \\
\hline Central African Republic & 4.950 & 62.4 \\
\hline Chad & 10.760 & 61.9 \\
\hline Congo & 71.712 & 59.2 \\
\hline Burkina Faso & 16.751 & 56.5 \\
\hline Nepal & 28.584 & 55.1 \\
\hline Haiti & 9.720 & 54.9 \\
\hline Angola & 13.338 & 54.3 \\
\hline Sierra Leone & 5.364 & 53.4 \\
\hline Mali & 14.160 & 51.4 \\
\hline
\end{tabular}


Borrowing from rich countries or international institutions, such as IMF and the World Bank are unconcerned with the well fare status of the common man in lending countries with the result that most of the money borrowed by the developing countries is spent on thing which are largely for the benefits of the rich and elite class of the society. Almost all the poor countries in the World are under heavy internal and external debt and still they are counted poor among the poorest nations of the world. A picture of the poverty level in the world is depicted above. In fact, poverty in the world is widely spread. In almost every country, rich or poor, there are people who are counted as the poorest. In the rich countries such poor people are the responsibility of the state and they are given full support for their comfortable living. In poor countries, the poor are left alone and are absolutely neglected.

Human Resource Empowering: People ought to play pivotal role in bringing change in the welfare of the common person. Poverty seems to have been imposed by those who command power and authority to distribute national resources. A change is eminent and the poor people have to stand up for their legitimate rights. The sequence of change is to reflect the following priorities:

- Basic Education/computer literacy compulsory for all

- Poor families given incentive payments to send their children to school

- Providing Skill Learning facilities for all

- Job or Maintenance Allowance

- Basic Health facilities for all at free of cost

Every person must be made to work for his/her own economic welfare. On positive response the national interest will be served and the Gross Domestic Product (GDP) will be accordingly affected.

Business Sharing: In countries where abundant labor is available and it is not fully employed, the wages are likely to be low. Rachael (2009) observed that in the global competition, many of the multinationals are trying to establish their links with these countries to get the low cost advantage by out sourcing many of the components they need to make for their final product. Electronics, auto parts, home appliances and ready made garments are some of the fields in which outsourcing business is expanding very fast.Poor countries have not taken full advantage of these opportunities, because they have not established a highly efficient network of suppliers. Still the labor employed in the vendor industry in these countries is not adequately educated, trained and skilled to use latest technology. The potential is there for the expansion of vendor industry as an excellent source to transform the low-income country to a high income and directly improving the standard of living of the common person. The capitalist must share his business with the potential suppliers of those parts/components where he can train them, give them short-term loans if needed, and engage them on the lines of Just-on-Time system of operations, so that all participants can make normal profits. Jeffrey (2003) concluded that the outsourcing is both cost effective and is becoming increasingly indispensible for the survival of business concerns in the global market competition.

Outsourcing Potential: The surplus labor in most of the developing countries lack necessary education, appropriate level of skills and sufficient training to improve their wage bargaining strength. The ability to provide a reliable and dependable supply of parts/components to national or international business concerns, it requires the suppliers to be able to deliver according to a specified time schedule and quality design. The possibilities of engaging families, individuals as suppliers and sub-suppliers for making components/parts for delivering to business companies, can be turned into a widespread network for employing unemployed/low income earners in the developing countries. Public sector authorities in these countries are to execute policy program to give financial help, tax concessions, and education and training subsidies to the needy. So far the common person in many of the developing countries is struggling to survive by continuous running around solving his family problems of poverty and ill health. Most of these people are under pressure and they cannot make rational decisions to assess make best use of their abilities and meager resources for earning There is no advisory assistance available to the poor people, from public or private sector, to provide help and guidance for adopting better and more income generating jobs, trades and professions. It should be the primary responsibility of the state to assess its human potential, and place it where the individuals can make best return for their living. This is how the national interest will be served.

\section{Existing Set-up of Vendor Industry}

The concept of vendor management was adopted recently by large enterprises to reduce costs and to increase competitive ability in the global market. With the emergence of e-Business, Business to Business 
and the like vendor management played significant role in strengthening closer ties between large enterprises and the suppliers. The online auction facilitated industrial suppliers to bid for the jobs and the enterprises saw substantial reduction for there purchasing requests. The vendor management system is a kind of contingent workforce management system. In fact, a vendor may be a person or organization that offers contingent labor. They are all called suppliers because they supply the labor under a contract rather than selling it directly to the buyer in the market. The vendor has to be very careful to provide quality goods and services at agreed upon pricing to maintain trust and creditability throughout the contract. The Key Performance Indicators, a measure of the efficiency of the supplier, are recorded to ensure that the supplier is performing precisely according to the contract. In fact, Vendor industry is an excellent means to motivate and provide skillful jobs to a large number of workers to earn and share income with the business concerns. Given the amount of surplus labor in many of the developing countries, the vendor mode of production can bring very many feasible solutions to provide income to the job less people in these countries on a regular basis.

Vendor Operations: Vendor scheduling seems to have placed major impact on the efficiency and productivity of vendor operations. According to Goddard (1986) Just--in -Time is a proven operational system capable of bringing cost savings on several accounts. Vendors providing raw materials and components Just-in-Time help the business concerns to save on many of the handling and storage costs to maximize profits. This way vendor scheduling seems to have placed major impact on the efficiency and productivity of vendor operations.

Vendor Management: Vendor management is an organized approach. The business concerns requesting supplies or services from a vendor are to appoint a formal Administrator to oversee the work to be performed by the vendor for the specified contract or agreement. To avoid any misunderstanding of the terms of agreement or contract, a document known as "Scope of Work" is prepared to accompany the agreement or contract. This actually spells out explicitly the responsibilities of all parties. The vendor management system thus provides an excellent training to hold commitments, deliver according to agreed design and quality and to build confidence and creditability among the vendors and the business concerns (Management Coaching, 2006).

Vendor Scheduling: The business concerns provide "vendor scheduling", which gives the vendor valid schedules broken down in weekly or smaller time periods. The vendor accordingly can build to that schedule and helps reduce the paperwork associated with the purchase orders, change orders, and follow-ups. In fact, vendor scheduling, allows a vendor to know what is needed and how much to deliver, and just when it is needed. This helps to build closer relationships between the business concern and their suppliers. Xerox, with 80 percent of their manufacturing business conducted with vendors; strongly believe in early vendor involvement. Toyota(Ohno. 1988) uses his long-term relationship with his suppliers by sending his staff to help suppliers improve their processes. These interventions have created a more reliable supply chain and lowered prices for customers.

Outsourcing: Globalization has contributed a great deal to promote outsourcing as a means to cut costs. Many of the multinationals selling automobiles, household electronic appliances, fashion garments and readymade clothes and the like are getting their components from countries where the skilled labor and the material inputs are cheaper and management costs are lower. Many of the multinationals have already contracted countries where there is a security and law and order prevails to the satisfaction of the businesspersons. China, Malaysia, India and Bangladesh are the places where outsourcing is one of the key factor in cutting cost of the products sold internationally. In automobile manufacturing, Toyota assembly plant covers only 15 percent of total manufacturing in-house (Schonberger, 1982). The rest of 85 percent of the process involves manufacturing more than 10,000 individual parts and assembling them into about 100 major components including engines, suspension systems, and trans-axels. Toyota worked closely with its suppliers, providing them with management expertise, engineering expertise, and some time capital to finance new investments. As a consequence of this strategy, Toyota out-sources more than any other auto manufacturer.

Vendor Industry-Trend Setters: India and China are likely to be the hub of manufacturing small cars in the world (Report, "For India's Auto Industry, the Race is on"). These two countries have large population base (China 1.35 billion, India 1.19 billion -Year 2011) and are capable of providing various auto components at relatively lower costs. A survey by the Economist (Year 2011) expects $60 \%$ of the incremental demand of 2.8 million vehicles to come from Asia by 2020, with China and India topping the 
charts. The CEO of Renault and Nissan in India was of the view that sourcing cars from India for the world markets is 35\% cheaper than Europe. Tata Motors (One of the big auto manufacturer groups) sells its light commercial vehicle for nearly $\$ 3000$ and it is $80 \%$ outsourced. A similar proportion of outsourced parts are used by the market leader Marutiin India. Auto industry in India is rapidly growing due to fast expansion in the middle-income families, GDP growing close to 9 percent and auto prices declining on account of drop in auto costs and intense global competition. Nissan (Japan), Renault (France), in collaboration with Mahindra and Mahindra (Indian Tractor Manufacturing giants) are in the process of establishing manufacturing car plant at Chennai for the production of initially 400,000 cars with a provision to increase production to reach 800,000 cars per annum in the later years. Autopolis,, a British consulting firm, came to the conclusion that the top six global auto companies will lose market share to companies like FAW and SAIC in China and India's Tata Motors. MacDuffie (2007)an associate professor from Wharton, an automobile industry expert, further supported the view that on account of better performance of Indian economy domestics auto market is to expand rapidly. The total automobile manufacturing in India is likely to reach 2 million cars per annum.

Low Cost-Driving Force: The driving force behind auto manufacturing explosion in India largely came on account of lower cost of production. This was made possible due to India's strong base of auto ancillary manufacturers. In India there are several auto parts suppliers like Hero-Honda, and then there are subsidiaries, who gather skill workers of the quality and quantity needed to perform the contracted jobs. The subsidiaries are well organized and competent to supply the precise quality required by the principle vendors. Mercedes Benz presence in India shows that its revenue earned from exports of auto parts from India exceed its revenue earned from domestic sales. Toyota Kirloskar, an auto parts manufacturer earned nearly \$ 1 billion largely from exports. In fact, auto manufacturers, both local and foreign business concerns, they are trying to develop vendor bases in India. Hyundai has brought in vendors of his own from Korea and they have been settled near their plant in Chennai. All these and many other factors relating to cost savings have attracted Ford, GM (USA), Nissan (Japan), Renault, Peugeot (France) established their interest in India.Pakistan, a country with plenty of labor, at relative cheaper rates, seems to be contributing a great deal in the promotion of vendor contracts. The auto industry in Pakistan (Gulf Economist, 2011) isexpanding very fast, and there is a growing demand for parts and components by Pakistani auto dealers. The number of vendors making various auto parts is growing and the contingent workforce is becoming highly competitive. There are around 200,000 people employed in the auto industry, majority of them are contingent workforce. Auto-part exports are around \$20 million per annum. Due to deletion program, 60 to 75 percent of the auto parts are being manufactured locally and are outsourced.

Future Pattern of Growth of Vendor Industry: Vendor industry provides competitive strength among the workforce to do the job professionally to meet the standards of the entrepreneurs. The poor countries have ample labor. Majority of them are not fruitfully employed. If they are not employed because they do not have basic education, required skill to perform their duties, no money to do business on their own, then definitely there is an important role which the state must play to enable them to contribute income for their own living and as well as add value to the country's GDP. Globalization is to bring revolution in market economies. The consumers' ability to choose and select products/services will increase to their advantage at a relatively lower price and with higher satisfaction. All this will be possible on account of fast changing cost efficient technology and highly competitive market conditions. Soon economies of scale will cease to be cost efficient, and small producers will gain upper hand in reducing their cost of production, adopting new technology and producing highly customized products.Looking at the scale at which human power in the poor countries can be mobilized, the future trend in consumer choices and the technology change effecting cost of production, it can be safely said that smaller business units will become more feasible and can be run efficiently if they are allowed to come in and given initially the necessary financial and legal support to take off.

Considering various alternatives to engage available labor force for fruitful employment in the developing countries, auto industry can provide better opportunities to earn respectable living for the skilled workforce. China, India, South Korea and Malaysia are some of the countries where vendor industry has been seen extremely effective in making positive contribution to their GDP, cutting cost of production, and providing specialized skills to strengthen their bargaining ability when negotiating work contracts with the entrepreneurs.As majority of the population living in poor countries is least skilled and uneducated, the government in these countries has to come up with a realistic program of compulsory education and financial assistance for the benefit of low-income families. Definitely human resource is a 
very powerful means to gain economic strength when trained and employed. In this case the poor countries have to assign highest priority to programs, which favor economic welfare of the common person. If the ruling class in the poor countries is dedicated and sincere then the solution to activate people in these countries can be successfully implemented.

Compulsory Education: As a first step universal primary education must be planned and executed with the help of qualified teachers to ensure its recognition for learning useful skills or receiving further education. This may require paying cash as incentive payments to the poor families who might not afford to send their children to schools and instead put them on jobs to earn income for supporting the family.Primary education curriculum must be uniform in all places (urban/rural) and should be consistent with the global changes and technological advancement experienced by the developed countries. As a matter of fact, every country must train its labor in accordance with its own factor endowments to provide marketable skills to the people for earning income to live respectfully in the society.

Business Adventures: It is the primary responsibility of the government to provide jobs to its citizen. Due to financial resource constraints, developing countries are not in a position to lend money to its citizens. However, on the lines of GrameenBank, the qualified skilled workforce should be allowed to borrow money on suitable terms if they want to make best use of their own skill to offer marketable services. The commercial banks/NGOs can perform very useful services in processing and monitoring the loaning procedures and getting the money back into the pool of reserve funds.

Short Term Bank Loans: We have an excellent model of working of Grameen Bank in Bangladesh, which can be transplanted and made workable in poor countries where people are looking for small finance to do business on their own. The terms and conditions of providing small loan can vary to suit the circumstances and the nature of business the poor people can start on their own. Apparently, the rulers of the poor countries are themselves reluctant to offer financial assistance to the poor and resource less individuals. In some of the developing countries billions of dollars have been written off, as nonperforming loans by the rulers to please the influential and big businesspersons of the society.

Vendor Industry: Future Trend: Poor countries have to use human resource as the most effective tool for competing in the global market. In the future, demand for two/three wheelers/small cars are likely to grow faster then many of the products manufactured for consumer use. With rapid awareness on account of globalization and media revolution, small cars are likely to be an essential part of a basic need for an average family living. To ensure small car affordability by an average family, the prices of autos have to be low, rather very low. Just as motorbikes are taking over bicycles in rural and urban areas of many of the poor countries, we see fast changing standard of living in many of the countries will replace bicycles/motorbikes with small cars. Production of small cars will be cheaper, if all of its components are outsourced. China, Korea and India are keen to develop their vendor industry with a view to become small car hub of the world. If China and India can do it, why not other countries where human power is available in large quantities but not making very significant contribution to their own welfare. Many countries in Asia and Africa can be made smaller hubs for producing various auto parts at prices, which can help to make small cars cheaper for the average family to buy. Henry Ford did it in the year 1926 at Rouge Plant (USA) when he started producing autos on conveyor belt and slashed the price to make it affordable to many more people (Heizer and Render, 2011). He reduced the price of "T" model from US\$ 780 to $\$ 360$ (a reduction of some $54 \%$ ).

The number of autos, especially two wheelers/three wheelers and small cars are rapidly increasing in many of the poor countries in Asia and Africa. Apparently it is late but not too late to prepare the poor people in these countries to have adequate education, learn appropriate skills and be prepared to start a small business of their own. This may be the message for all, but we also need some entrepreneurs with leadership qualities, who can form their own teams and bring some specific auto part as their specialty. In the same category we may see some investors ready to establish business firms as recognized suppliers of quality auto parts to the indigenous as well as to the auto manufacturers out side the country. Actually the vendor industry needs skilled labor on a large scale, finance to do business, and firm orders/contract to supply according to the schedule agreed. From among the vendors, very many skilled people may have the ability and interest to be a leader/coordinator and negotiator to form a viable team of workforce to produce auto parts. Such people can motivate and bring in investors to hold corporate responsibilities. 
The sequence of the vender industry setup will show the following linkages for adopting a competitive edge in the supply of auto parts in human resource rich countries:

- Education-(capability to handle computer aided designs)

- Skill Learning-(interest and hand-on-experience of making auto parts)

- Time Management-(Commitment to deliver according to schedule agreed)

- Capability to Get Loan- (Have sufficient creditability to be trusted for returning the loan)

- Market Awareness-(Fully conversant with the auto parts market conditions)

- Competitive Strength-(Can perform with greater efficiency and speed to reduce costs)

- Leadership-(Ability to hold team of the workforce together and keep Investors fully satisfied)

\section{Results and Discussion}

When Henry Ford setup Rouge Plant to assemble automobile ("T" model), the manufacturing set up was huge, running into kilometers, he wanted everything, including rail track, steel mill, glass manufacturing plant, to be under his own umbrella. The cost of " $\mathrm{T}$ " model was down from $\$ 780$ (Piecemeal handling of manufacturing) to $\$ 360$ (using assembly line production system). A very good demonstration for the economists to justify the use of such concepts as division of labor, and economies of scale. Since Toyota System came in there was a new revolution in the production process. Japanese handled every thing in parts. The manufacturing process was divided into various sections to be handled through out sources. This pattern of manufacturing automobiles proved to be highly cost efficient and the Japanese seem to have taken over leading role in making cars all over the world... Japanese adopted JIT, Kanban and Lean production systems mainly for cutting costs and this has increased the affordability of the common person to buy two wheelers. In fact, due to drop in the price of cars, the purchase of small car for an average family living in less developed countries is becoming part of basic necessities along with other necessities of life. Vendor industry is not cost efficient in countries where labor is costly. Less developed countries with surplus labor can deliver all what is required provided they get the basic education and training to match productivity standards of the western countries. We see almost all the big auto manufacturers trying to establish their links with countries where they can have access to well-trained labor and relatively lower overhead costs. China and India are the most attractive destinations for processing auto parts for multinationals.

\section{Conclusion and Recommendations}

Developing countries have all the important ingredients to transfer their countries into highly competitive self-sustained economies among the global setup. Countries like Pakistan, Nigeria, Sudan and Zambia are excellent examples where the economies can be turned around. So far the failure of these countries to gain status of a developed economy is largely attributed to the mismanagement of national resources by the rulers of these countries. Population is a most valuable and highly cost efficient resource available in abundance in many of the developing countries. Its effective use has been neglected and national resources seem to have been diverted to those uses where the benefits are being shared only by a few and powerful elite of the society. Due to media revolution, a change is very much in the offing, where economies will be forced to make best use of their human and material resources in order to survive among the growing global competition. The vendor industry in developing countries is likely to generate widespread employment and income to empower the common person to live a comfortable life with respect and dignity. In the field of auto parts manufacturing, the experience of China, India, Korea and Malaysia provide excellent example of engaging skilled workers to a supply chain, where auto parts are outsourced to a number of suppliers for gaining cost efficiencies for a competitive global market. The developing countries with abundant labor can make best use of this valuable resource by providing them basic education, and skill-learning opportunities on professional lines free of cost. All qualified skilled labor may be given small loans (repayable on convenient terms) to enable them to start their own business.

Womack et al. (1991) were of the view that the Lean production system and Just-in-Time system of handling production processes require, outsourcing almost all the components in the manufacturing process of a product. Many multinationals in order to cut down their costs have shifted their businesses to less costly destinations in developing countries. China, Malaysia, India and Bangladesh seem to be gaining all the benefits on account low labor cost and relatively much less overhead expenses. Vendor industry is providing low cost advantage on several accounts, including tax concessions, low utility costs, low transport costs, low labor costs, low overhead expenses, and several suppliers ready to offer their 
services/products at highly competitive rates. All this goes to confirm that the trend in outsourcing various components by big businesses (domestic or international) will be a major factor in bringing revolution in economic growth and promoting economic welfare of the common person in developing countries. Due to globalization and media revolution the pattern of demand is increasing very fast. Now more and more families are ready to work harder to be able to afford better standard of living. The number of autos, especially two wheelers/three wheelers and small cars are rapidly increasing in many of the less developed countries in Asia and Africa. A trend, which will further promote cost efficiency of vendor industry in labor surplus countries to strengthen greater cost competition.

\section{References}

Automobile Industry. Pakistan Gulf Economist. (2011). Retrieved from For India's Auto Industry, http//www.pakistaneconomist.com/issue37/i\&e5.htm

Dowling, J., Malcom, S. \& Valenzuela, M. R. (2004). Economic Development Asia Thomson Learning Offices. Singapore.

For India's Auto Industry. (2007). The Race Is On: Size matters, and Price Does, Too. Published March 23, 2007 in India Knowledge @ Wharton

Goddard, W. E. (1986). Just-in-Time: Surviving by Breaking Tradition, Oliver Wight Limited Publications, Inc., 5 Oliver Wight Drive, Essex Junction, VT 05452

Heizer, J \& Render, B. (2011). Operations Management Ch. 11, 16, 17. Pearson Education, Inc. New Jersey. USA.

Jeffrey, L. (2003). The Toyota Way: 14 Management Principles from the World's Greatest Manufacture, First edition, McGraw-Hill, ISBN 0-07-139231-9.

MacDuffie, J. P. (2007). Managing People across Distributed Work. Wharton School, University of Pennsylvania

Management Coaching and Training Services. (2006). the Just-In-Time (JIT) Approach. Retrieved June 19, 2006 from the World Wide Web: [1]

Ohno, T. (1988). Toyota Production System: Beyond Large-Scale Production, Productivity Press, ISBN 0915299-14-3

Pilkington, A. (1998). Manufacturing strategy Regained: Evidence for the Demise of Best practice. California Management Review, 41(1), 31-42.

Rachael, K. (2009). Pakistan, a Popular Outsourcing Destination.Bloomberg Business Week. (305)

Schonberger, R. (1982). Japanese Manufacturing Techniques: Nine Hidden Lessons in Simplicity, Free Press, ISBN 0-02-929100-3

UNDP-Multidimensional Poverty $\quad$ Index. Wikipedia, the free Encyclopedia.http:/en.wikipedia.org/wiki/Multidimensional Poverty Index

Wadell, W.\& Bodek, N. (2005). The Rebirth of American Industry, PCS Press, ISBN 0-9712436-3-8

Womack, J. P., Jones, D. T.\& Roos, D. (1991). The Machine That Changed the World: The Story of Lean Production, Harper Business, 2003, ISBN 0-06-097417-6. 